\title{
電流パルス駆動によるアザラシ型位置決め機構の 高分解能化*
}

\author{
古谷克 司 ${ }^{* *}$ 太田徳幸 ${ }^{* * *}$ 古田 淳 ${ }^{\dagger}$ \\ Improvement of Resolution of AZARASHI (Seal) Mechanism by Current Pulse Drive
}

Katsushi FURUTANI, Noriyuki OHTA and Atsushi FURUTA

\begin{abstract}
The authors have proposed a driving method of a piezoelectric actuator by using current pulses for the high resolution. It was applied to the driving method of Extension device of AZARASHI (Seal) Mechanism. A device with 1 degree of freedom was designed for the improvement of the resonant frequency and resolution by using the finite element method. A piezoelectric actuator was used for a clamp of the controlled Friction device to improve the response time. The device runs along a double- $\mathrm{V}$ guide for the high motion accuracy. In Coarse mode, Extension device repeats the extension and contraction with its full stroke. Then, Friction device for a constant friction is positioned during fixing the controlled Friction device in Fine mode. In the case of the reference position of $100 \mu \mathrm{m}$, the settling time within $5 \mathrm{~nm}$ was $376 \mathrm{~ms}$.

Key words: piezoelectric actuator, current pulse, positioning, friction, accuracy, resonance frequency
\end{abstract}

\section{1. は じめに}

積層型圧電アクチュエータの変位は最大でも数十 $\mu \mathrm{m}$ 程度で あるが, ナノメータオーダ以下の高分解能な変位が得られる. 圧電アクチュエータの変位は, 印加電圧を変化させることで制 御することが多い1)2．コンピュータでコントローラを構成する 場合には, 通常は駆動信号を D/A 変換器で出力し, それをアン プで電力増幅して圧電アクチュエータに印加する. 変位センサ にリニアエンコーダなどを用いることで, 変位の測定のダイナ ミックレンジは大きくとることができる. しかし, 駆動側は D/A 変換器の分解能によりダイナミックレンジが制限を受ける. ま た，アンプ出力電圧にノイズが含まれると，それにともなう電 流が流れるため, 微小変位を安定させることが困難である. 一 方, 圧電アクチュエータに流す連続的な電流を制御することで, 充電される電荷量を制御し，ヒステリシスなしに変位を変化さ せる方法が提案されている ${ }^{3)}$.この場合も, 電流值を与えるため には D/A 変換器が必要になるため, 電圧源と同様の問題がある. そのため, 可動範囲が大きく, 分解能が高い駆動は困難であっ た.

電磁アクチュエータに関しては，パルス幅変調(PWM)により 速度制御が行われることも多い，さらに，入力に $\Delta \Delta$ 変換による $\mathrm{A} / \mathrm{D}$ 変換を用い, 出力にパルス密度変調を適用することで, 簡 単な構成で高精度に制御することが提案されている4)5). 圧電ア クチュエータでも, 印加電圧を PWM 制御することによりヒス テリシスが低減されることが報告されている ${ }^{6)}$. 著者らはフルス トロークにわたって高分解能を得るための駆動法として, 電流 パルスを用いた圧電アクチュエータの駆動法を提案した 7). 固定 されたパルス幅の電流值のパルスを印加するため電荷制御とな り, フィードバック制御だけでなくオープンループ制御でも使 用できるという利点がある.

$*$ 原稿受付 平成 19 年 6 月 14 日

**正会員 豊田工業大学 (名古屋市天白区久方 2-12-1)

***学生会員 豊田工業大学大学院 (現, プレサイスゲージ(株); 浜 松市北区三方原町 283-4)

†正会員（株)ナノコントロール（東京都品川区南大井 6 丁目 17 番 17 号)
一方, 圧電アクチュエータの伸縮量よりもさらに大きな変位 を得るために, さまざまな間欠移動機構が提案されている 8) 14). これらは, 走査型プローブ顕微鏡やマイクロマニピュレータの 位置決めステージのように, 広範囲にわたり高分解能が要求さ れる装置に多く用いられている. 著者らもアザラシ型位置決め 機構を提案した 15) 17). アザラシ型位置決め機構の粗動モードで は, 伸縮素子をオン・オフ制御し, ステップ状に移動する. 微 動モードではそれを補間するように伸縮素子を伸縮させ, 高精 度に位置決めする.インチワーム機構のステップ状の移動を補 間する機構としては, 変位用圧電アクチュエータを連続的に伸 縮させるウォーキングドライブ機構が提案されている ${ }^{18) .}$

本論文では, アザラシ型位置決め機構の伸縮素子の駆動に電 流パルス駆動法を用いることで, 間欠駆動である粗動モードと それを補間して連続的に駆動する微動モードを混合した位置決 めを行った結果について述べる.

\section{2. 原理}

\section{1 電流パルスによる駆動}

電流パルスを用いた圧電アクチュエータの駆動回路の構成を 図 1 に示す7). 複数の供給用電流源（カレント・ソース）と吸い 込み用電流源（カレント・シンク）を切り替えスイッチを介し て並列に接続し, それぞれのスイッチを導通させることで圧電 アクチュエータを駆動する.1 パルスあたりの駆動量は, 電流值 とパルス幅の積である電荷量により決まる. したがって, 変位 をフィードバックしなくてもヒステリシスの少ない駆動が可能 となる.

変位センサで圧電アクチュエータの変位を測定することでフ ルクローズドフィードバックを構成する. 目標值に対して偏差 が大きい場合には, 電流值の大きい電流源 $I_{\mathrm{p} 1}, I_{\mathrm{m} 1}$ で駆動し, 高速な伸縮を得る. 偏差が小さい場合には $I_{\mathrm{p} n}, I_{\mathrm{mm}}$ で駆動する. 偏差が変位センサで検出できる分解能以下になると, 電流パル スは印加されない. 電流源の内部インピーダンスは非常に大き いため, 駆動アンプは切り離された状態と見なすことができ, 変位が保持される. このように, 分解能の高い伸縮量を得るこ とができるパルス状の電流が圧電アクチュエータに流れるため, 


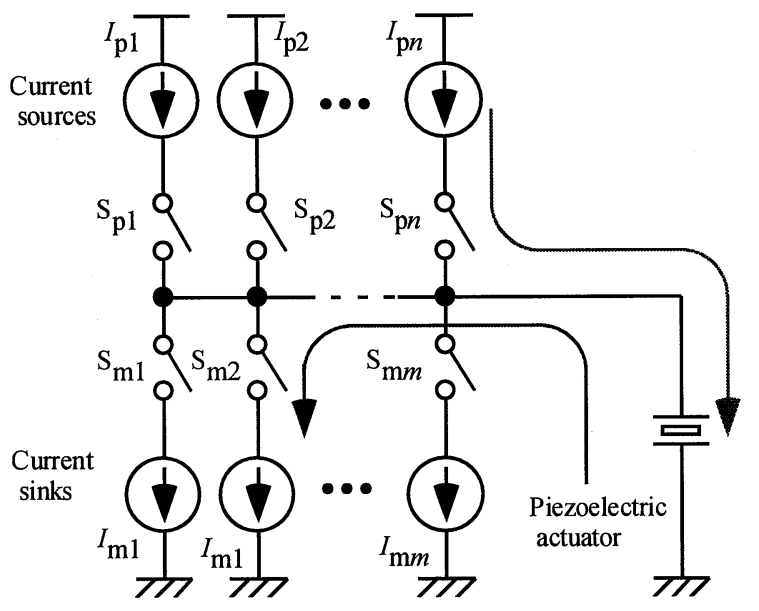

(a) Configuration of circuit

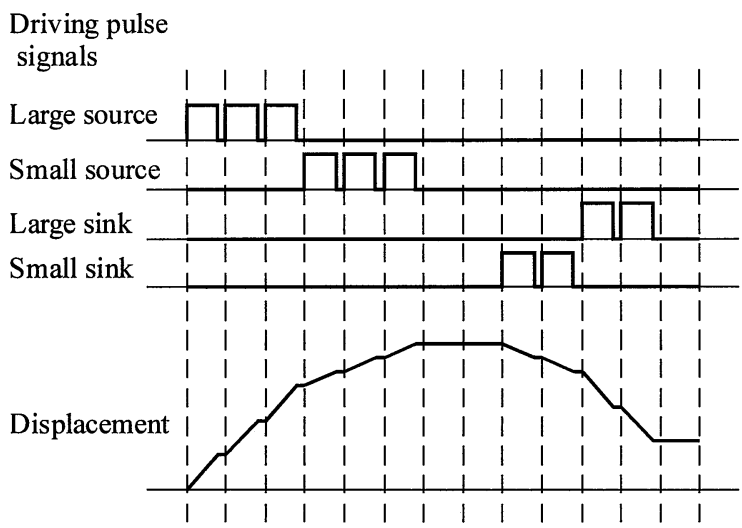

(b) Displacement

Fig. 1 Principle of driving method by using current pulse

電流值とスイッチのオン時間を調整することで, 精密な值の電 荷量を与えることができる．したがって，ステッピングモータ のように，与えるパルス数により変位を制御することができる.

電圧パルスで駆動する場合には，一定変位で保持される場合 でも常に電流が流れる. そのため, 電力損失が発生する 19$)$. こ の点で, 電流パルス駆動のほうが優れていると考えられる.

\section{2 アザラシ型位置決め機構}

一自由度アザラシ型位置決め機構の構造と移動原理を図 2 に 示す 15) 17).

一軸用移動機構は 2 個の摩擦機構 A, B と 1 個の伸縮素子か ら構成される. 伸縮素子の両端に摩擦機構を取り付け, それを ベース上に置く. 摩擦機構 A は一定摩擦力とされており, 摩擦 機構 $\mathrm{B}$ のみがオン・オフ制御される. 摩擦機構 $\mathrm{A}$ における一定 摩擦力を $F_{\mathrm{C}}$, 摩擦機構 $\mathrm{B}$ の摩擦力を強めた時の摩擦力を $F_{0 n}$, 弱めた時の摩擦力を $F_{\text {Off }}$ とすると,

$$
F_{\text {Off }}<F_{\mathrm{C}}<F_{\text {On }}
$$

の関係が成り立つように調整しておく. 摩擦機構 B がオンの時 に圧電アクチュエータを伸縮させると, 摩擦機構 A が変位する. 摩擦機構 B がオフの時に圧電アクチュエータを伸縮させると, 摩擦機構 B が変位する.

粗動モードでは，以下のサイクルを繰り返すことにより左に 進む. 最初は伸縮素子を縮めておく.

（1）制御用摩擦機構 B をオフにする.

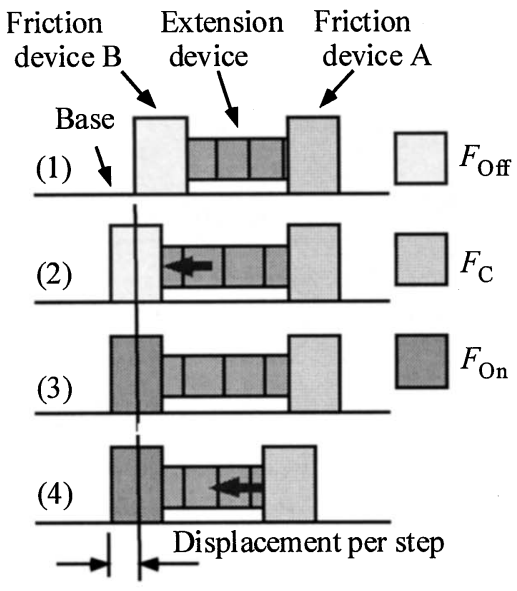

Fig. 2 Principle of movement of AZARASHI mechanism with 1 degree of freedom.

(2) 摩擦機構 A における摩擦力のほうが摩擦機構 B におけ る摩擦力より大きいため, 伸縮機構を伸ばすと摩擦機構 A は 止まったまま摩擦機構 B が左に移動する.

(3) 摩擦機構 B をオンにする.

(4) 摩擦機構 A における摩擦力のほうが摩擦機構 B におけ る摩擦力より小さいため, 伸縮機構を縮めると摩擦機構 A が 摩擦機構 B 側に引きつけられるため, 機構全体は左に進む.

これで 1 周期の移動が完了する.

伸縮機構の伸縮を逆にすることで，反対向きへ移動すること も可能である.この動作は，アザラシが後足をすりながら移動 する様子に似ているため, アザラシ型機構と呼ぶことにする. 摩擦機構 A が後ろ足に相当する.

伸縮機構を粗動モードのステップ状の移動を補間するように 伸縮させる微動モードと組み合わせることで, 高精度な位置決 めが可能になる ${ }^{16)}$.

\section{3. アザラシ型移動機構の設計}

これまでに製作したアザラシ型移動機構は，伸縮素子に圧電 アクチュエータ, 摩擦機構に電磁石を用いていた 15) 17). 使用し た電磁石は応答が遅く，オフしてから圧電アクチュエータを動 作させるまでに約 $10 \mathrm{~ms}$ の時間が必要であった．また，発生で きる摩擦力が弱く，圧電アクチュエータを高速に伸縮させると 電磁石が滑ることがあった 20). そのため, 粗動モードでは 1 ス テップあたりの移動量が減少し高速移動が困難になり, 微動モ ードでは高分解能な位置決めが困難になる恐れがあった。

そこで, 摩擦機構の応答性の改善と摩擦力の向上を図るため に，電磁石の代わりに積層型圧電アクチュエータを用いた．積 層型圧電アクチュエータは電磁石に比べ応答性が高く, 発生力 も大きい，そのため，機構を強力に保持し，高速に動作させる ことが可能となる.

伸縮素子である積層型圧電アクチュエータの伸縮量は $10 \mu \mathrm{m}$ 程度であるため, 速度を増大させるためには駆動周波数を高く する必要がある，そこで，伸縮素子と制御用摩擦機構の固有周 波数が $1 \mathrm{kHz}$ 以上となる構造となることを設計指針とした．構 造の決定には，有限要素法による解析結果を利用した.

製作したアザラシ型位置決め機構の構造を図 3(a)に示す. 伸 縮機構とオン・オフ制御する摩擦機構, そして一定摩擦力を与 える一定用摩擦機構から構成される. 伸縮機構と制御用摩擦機 


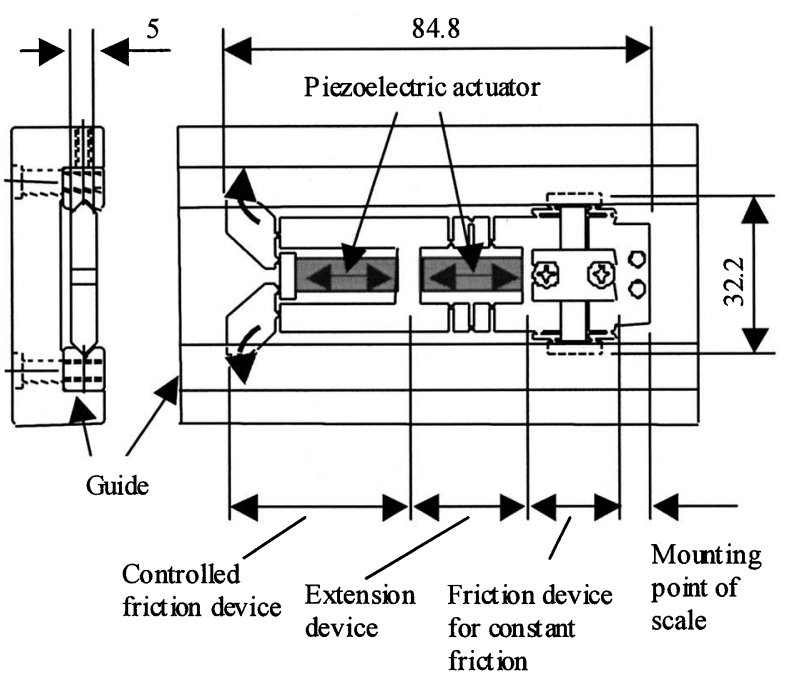

(a) Whole device.

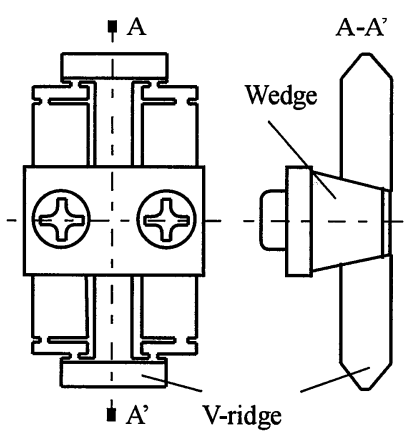

(b) Friction device for constant friction Fig. 3 Structure of AZARASHI device with 1 DOF

構は炭素鋼(S50C)製で, アクチュエータには積層型圧電アクチ

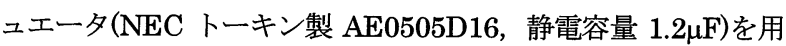
いた. 摩擦力を発生させるために機構の外側にガイドを設け, それに摩擦機構を押し付けることで摩擦力を発生させた. 機構 の直進性を向上させるために，ガイドは両 V ガイドとした。

同図(b)に示した一定摩擦機構では，ねじを締めることにより 中央のくさびが押し込まれ, 両側の V 字形突起がガイド側に押 される. 制御用摩擦機構では, 先端を V 字形突起にしたてこに より圧電アクチュエータの変位を拡大する. 支点と力点は同図 (c)に示す弾性ヒンジにした. アクチュエータを伸ばすと先端が アクチュエータの伸長方向に対して垂直方向に変位し，ガイド に押し付けられる. 圧電アクチュエータを伸ばしていない状態 では，突起とガイドとの間にはわずかなギャップがあるため, 摩擦力は低い. 先端に生じる変位は, てこの寸法比から計算す ると圧電アクチュエータ単体の変位の 2 倍となる.

伸縮機構の側面には弾性ヒンジを設けることで圧電アクチュ エータの伸縮が可能になるとともに, 圧縮応力がかかるように した. そして, 圧電アクチュエータの全長に対して $20 \mu \mathrm{m}$ 短く した機構にはめ込むことで, 圧電アクチュエータに予圧をかけ て固定した.

有限要素解析に用いたモデルを図 4 に, 物性值を表 1 に示す. 圧電アクチュエータを弾性体として扱い，その両端が機構の枠 に固定された状態とした.メッシュ分割には，主に 8 節点四角 形要素を使用し, 部分的に三角形要素を用いた. 設計に当たっ

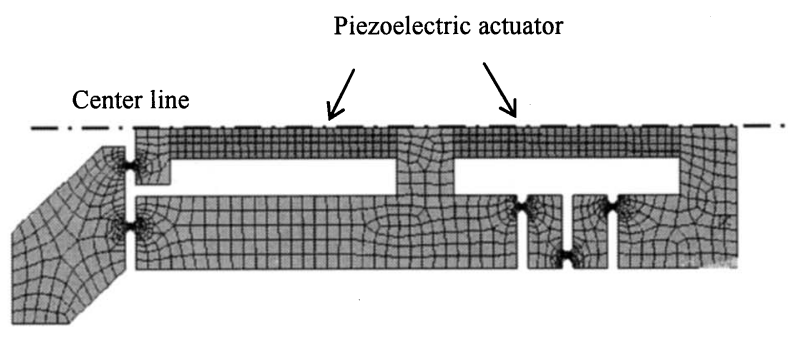

Fig. 4 FEM model of movable part

Table 1 Properties of materials used in FEM model

\begin{tabular}{lcc} 
Table 1 & Properties of materials used in FEM model \\
\hline & S50C & Piezoelectric actuator \\
\hline Density kg/m ${ }^{3}$ & 7870 & 8000 \\
Poisson's ratio & 0.3 & 0.3 \\
Young's modulus GPa & 210 & 44 \\
Damping coefficient & 0.01 & 0.01 \\
\hline
\end{tabular}

Table 2 Natural frequency (1st mode) of device

\begin{tabular}{lcc}
\hline & FEM analysis & Experiment \\
\hline Extension device & $5.627 \mathrm{kHz}$ & $5.25 \mathrm{kHz}$ \\
Friction device & $5.499 \mathrm{kHz}$ & $5.47 \mathrm{kHz}$ \\
\hline
\end{tabular}

ての制約条件は以下の 3 点である.

（1）降伏を防ぐために最大ミーゼス応力 21 は 350MPa を越 えない

（2）変位拡大率が大きくなる.

(3) 固有振動数が高い.

その結果, 制御用摩擦機構と伸縮機構の弾性ヒンジは, 最細 部の幅が $0.5 \mathrm{~mm}$, 半径が $0.5 \mathrm{~mm}$ の円弧状となった. 固有振動 数を解析した結果を表 2 に示す. 解析結果より機構の固有振動 数は $5 \mathrm{kHz}$ 台となった.

ステップ応答時の自由振動を周波数解析して求めた伸縮方向 の 1 次固有振動数を表 2 に示す. 圧電アクチュエータに高さ $100 \mathrm{~V}$ の電圧を印加したときの各部の変位を静電容量式変位計 (周波数帯域 $100 \mathrm{kHz}$ ) で測定し, 共振周波数を求めた.これらは 解析結果と一致した. 圧電アクチュエータの剛性が高いため, 弾性ヒンジを用いても固有振動数は高かった.

\section{4. 実験}

システムの構成を図 5 に示す. 電流源はソース, シンクとも に $0.5 \mathrm{~mA}, 20 \mathrm{~mA}, 1 \mathrm{~A}$ の 3 種類を並列に接続した. すべてのパ ルスの 1 周期を $100 \mu \mathrm{s}$ で一致させた. この場合の 1 パルスあた りの圧電アクチュエータの変位量を表 3 に示す. $1 \mathrm{~A}$ の場合には パルス幅が短く, 立ち上がりの遅れの影響がでたため, ほかの 電流值による駆動よりも変位が小さくなった. アザラシ型位置 決め機構の粗動モードにおける伸縮素子の駆動にも電流パルス を用いた. 制御用摩擦機構は通常の電圧源のリニアアンプ(周波 数帯域 $500 \mathrm{kHz}$ ，最大電流 $5.66 \mathrm{Ap}-\mathrm{p}$ ) でオン・オフ制御した. コ ントローラにはパーソナルコンピュータを用いた. 電流パルス 駆動回路へはディジタル $\mathrm{I} / \mathrm{O}$ ボードから, リニアアンプへは D/A 変換ボードから信号を与えた．変位はリニアスケール(分解能 $0.07 \mathrm{~nm}$ ) で測定し, ディジタル I/O ボードからデータを取得した.

圧電アクチュエータは容量性負荷であるため, 電流パルスは 積分される. そこで伸縮素子一電流パルスを与えるために $\Delta$ 変換 を用いた。 一つの電流值分のブロック線図を図 6 に示す. しき い值を超えた場合には, ソースまたはシンクを駆動するための パルスを出力するとともに 1 ビット D/A 変換器からパルスを出 


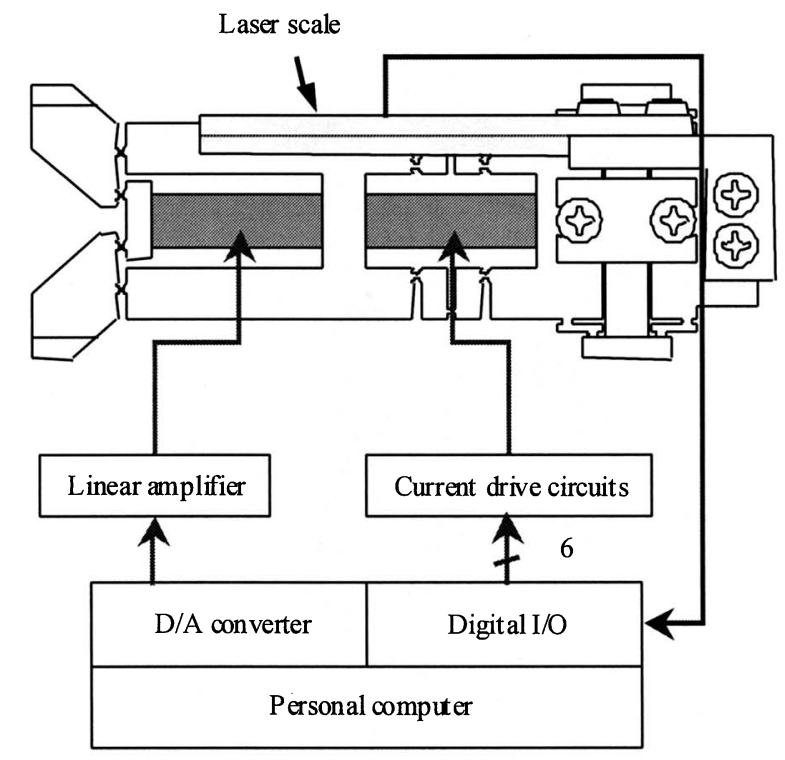

Fig. 5 System configuration for 1-DOF device

Table 3 Step of displacement

\begin{tabular}{cccc}
\multicolumn{5}{c}{ Table 3 } & Step of displacement \\
\hline & Current & On-time $\mu$ s & Displacement nm \\
\hline Coarse & Mixed & - & 8300 \\
\hline \multirow{3}{*}{ Fine } & $1 \mathrm{~A}$ & 16 & 720 \\
& $20 \mathrm{~mA}$ & 80 & 100 \\
& $0.5 \mathrm{~mA}$ & 80 & 2.5 \\
\hline
\end{tabular}

カし, 積分して目標值との偏差を計算した. したがって, 実際 にはパルス密度変調になる.

粗動モードの駆動例を図 7 に示す．縦軸のいはそれぞれのゼ ロを示す. ディジタルオシロスコープで記録したため, ソース およびシンクの信号がまばらに見えているが，実際には高密度 に出力されている．電流值を切り替えながら駆動することで伸 縮素子を $5 \mathrm{~ms}$ で放物線状に変位させた．伸縮素子および摩擦機 構の動作後の待ち時間はそれぞれ $2 \mathrm{~ms}$ とした. したがって，粗 動モードの 1 周期は $18 \mathrm{~ms}$ である. 摩擦力は, 制御用摩擦機構 のオン時は $19.2 \mathrm{~N}$ ，オフ時は $0.4 \mathrm{~N}$ ，一定摩擦力は $5.1 \mathrm{~N}$ であっ た．同図のソースとシンクの駆動信号は $1 \mathrm{~A}$ 用である.

位置決め時には，まず目標値を超えない位置まで粗動モード で駆動する．次に，微動モードに切り替え，伸縮素子を伸縮さ せて位置決めを行う．偏差に忘じて電流パルスの大きさを切り 替えた. 一定摩擦用の摩擦機構では乾燥摩擦状態であるため, 比例一積分補償器を用いるとリミットサイクルを生じやすくな る.したがって，比例補償器を用いた.

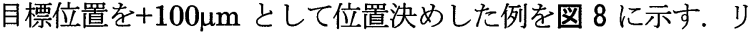
ニアスケールからの信号をフィードバックしながら比例制御を 行った. 偏差が表 3 に示した各電流值の伸縮量に入ったときに, 1 段階細かい伸縮量の駆動に切り替えた．約 $200 \mathrm{~ms}$ までは粗動 モードで移動したため, 大きなステップ状の動きが観察できる. その後, 微動モードに切り替わった. 微動モードでは, 制御用 摩擦機構をクランプし，一定用摩擦機構を変位させた．機構全 体を炭素鋼で製作しているため，大きく振動を減衰させる要素 がない，また，固体摩擦であるために，スティックスリップが 発生した可能性もある. その結果, 固有振動数よりはるかに低 い $24 \mathrm{~Hz}$ の振動が残ったと考えられる.

1000 回位置決めした場合に所定の誤差以内に入る整定時間 のヒストグラムを図 9 に, 平均と標準偏差を表 4 に示す. $5 \mu \mathrm{m}$

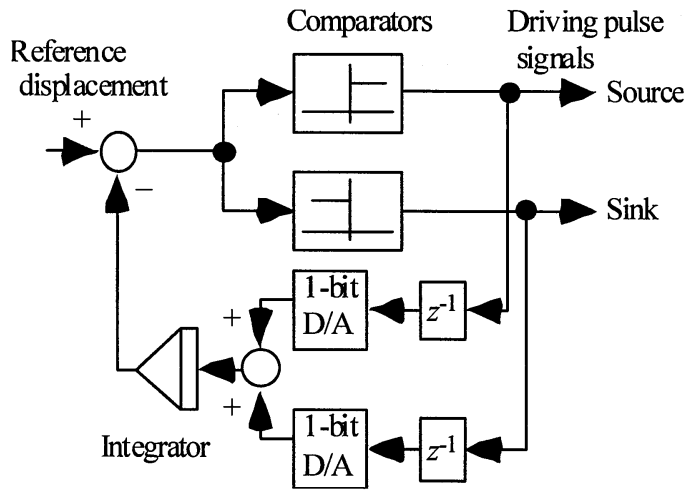

Fig. 6 Configuration of $\Delta$ conversion

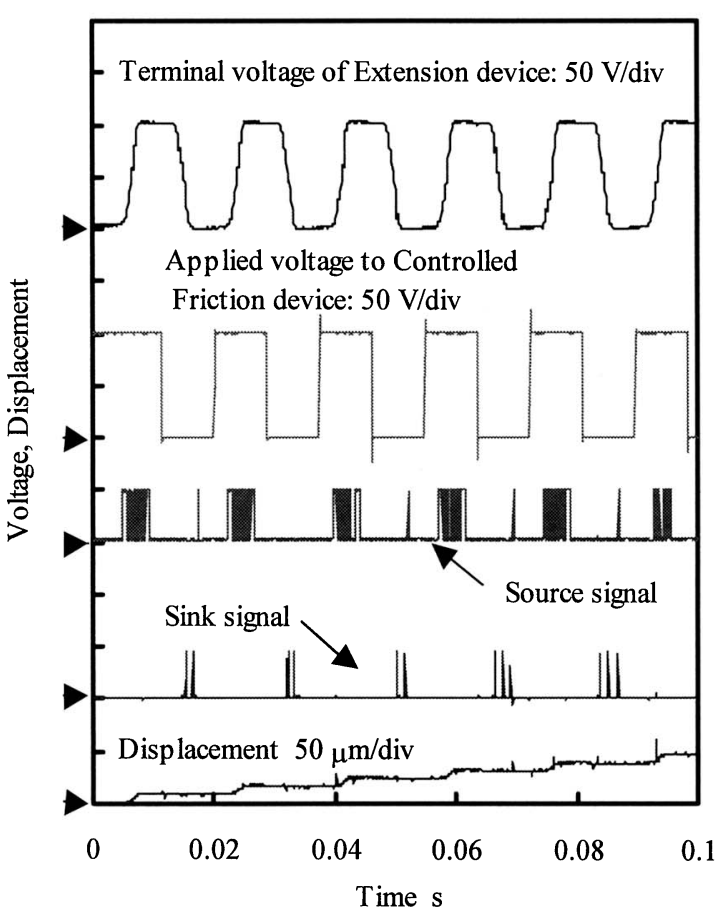

Fig. 7 Example of Coarse mode

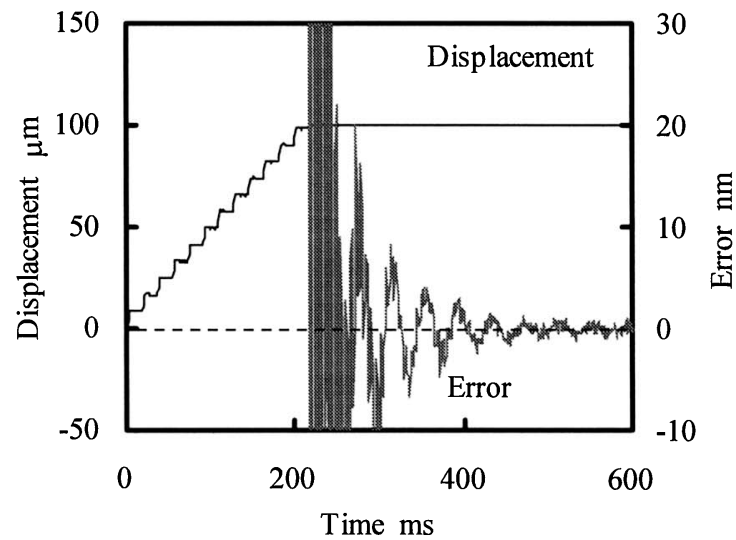

Fig. 8 Example of positioning (reference: $+100 \mu \mathrm{m}$ )

までの整定時間はほとんどが 220〜225ms に入っている. それ 以外の場合は, 粗動モードの 1 ステップ分の変位がすべりによ り小さくなり，ステップ数が 1 つ分だけ多くなり，1 周期分の 


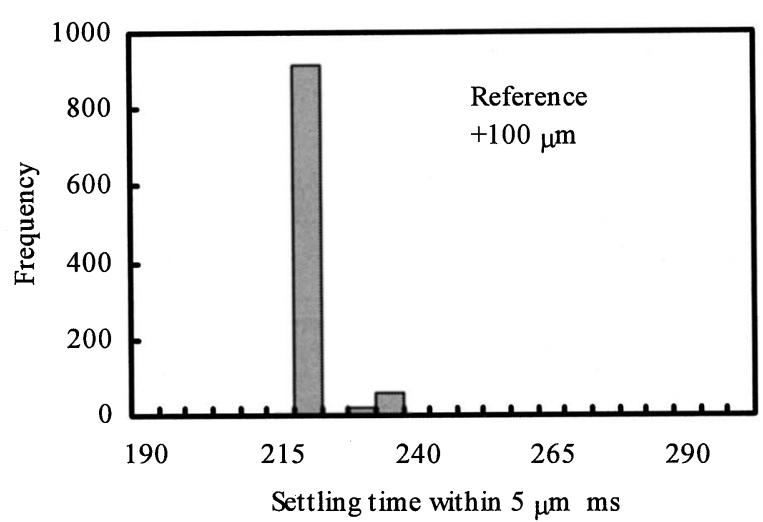

(a) Settling time within $5 \mu \mathrm{m}$.

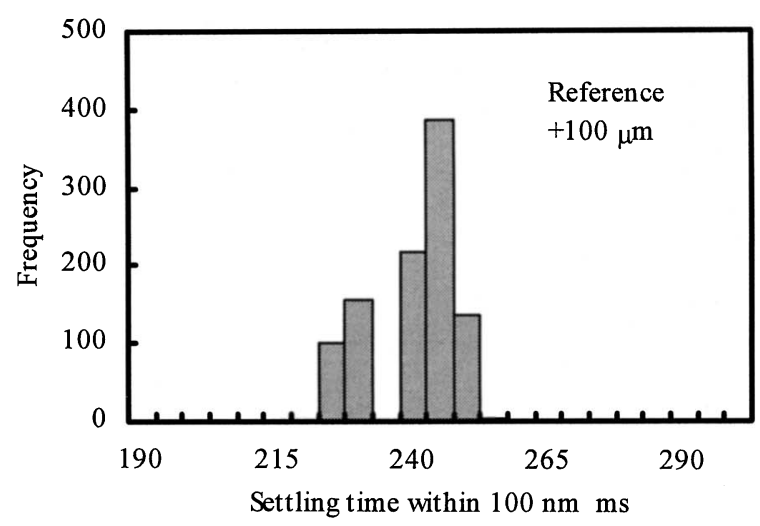

(b) Settling time within $100 \mathrm{~nm}$.

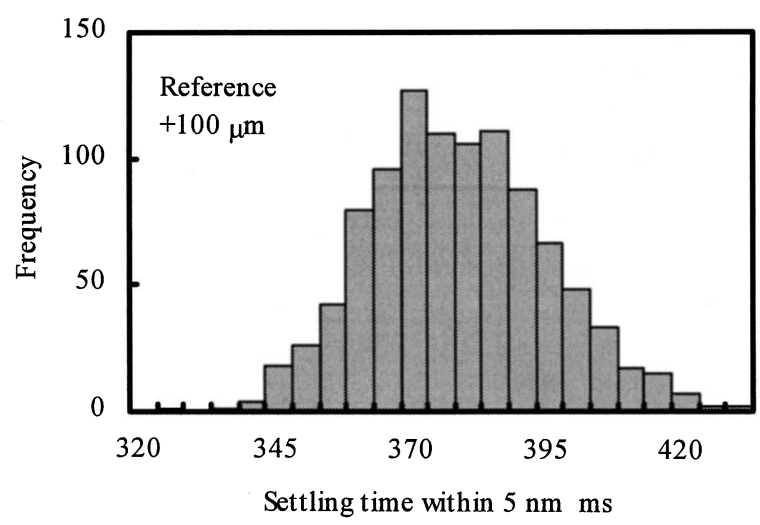

(c) Settling time within $5 \mathrm{~nm}$

Fig. 9 Settling time (reference: $+100 \mu \mathrm{m})$

$18 \mathrm{~ms}$ だけ時間が延びたことが原因であると考えられる. 位置決 め精度が高くなるほど整定時間のばらつきが大きくなった。こ れは，上で述べた残留振動の影響が大きいと考えられる.

伸縮素子も制御用摩擦機構を駆動したのと同じリニアアンプ で駆動した場合には，駆動周期を $6 \mathrm{~ms}$ まで短縮できた。そのと きの最高速度は $1.8 \mathrm{~mm} / \mathrm{s}$ であった.

\section{5. 結言}

本論文では, アザラシ型位置決め機構の伸縮素子の駆動に電 流パルス駆動を適用した結果について述べた.

(1) 摩擦機構にも圧電アクチュエータを用いることで固有 振動数が $5 \mathrm{kHz}$ 以上となる機構を製作した.
Table 4 Settling time (reference position: $+100 \mu \mathrm{m}$ ).

\begin{tabular}{ccc}
\hline & Average ms & Standard deviation ms \\
\hline $\pm 5 \mu \mathrm{m}$ & 219.0 & 4.4 \\
$\pm 100 \mathrm{~nm}$ & 237.6 & 7.5 \\
$\pm 5 \mathrm{~nm}$ & 375.7 & 16.4 \\
\hline
\end{tabular}

（2）粗動モードと微動モードを組み合わせてナノメータオ ーダの位置決めをした。

今後はパルス印加法を変更することで, 駆動時に発生する振 動の減衰を試みる予定である.

\section{謝 辞}

実験の遂行にあたりナノコントロール・飯田克彦氏，森浩一 氏にご協力いただきました。

本研究の一部には, 文部科学省平成 16〜20 年度科学研究費補 助金特定領域研究「アクチュエータ」(16078214)を用いました. 記して感謝いたします。

\section{考 文 献}

1) W. L. $\mathrm{Xu}$ and L. Han: Piezoelectric actuator based active error compensation of precision machining, Meas. Sci. Technol., 10, 2 (1999) 106.

2) D. Zhang, C. Chang, T. Ono, M. Esashi: A piezodriven XY-microstage for multiprobe nanorecording, Sens. Actuators, A108, 1/3 (2003) 230.

3) C. V. Newcomb and I. Flinn: Improving the Linearity of Piezoelectric Ceramic Actuators, Electron. Let., 18 (1982) 442.

4) T. Fukui, M. Segawa, M. Kurosawa, K. Oka, T. Higuchi: A control System with single-bit digital processing, Proc. Int. Conf. Control, Autom. Rob. Vision, Singapore (1996) 1992.

5) 東条啓一郎, 黒澤 実, 岡 宏一, 樋口俊郎 : 1 ビットディジタル信 号処理を用いた制御の分解能と情報量についてのシミュレーション, 電学論, 118-D, 5 (1998) 623 .

6) 池辺 洋, 中田 毅: 電わい素子を用いたサーボ弁の研究, 計測自 動制御学会論文集, 7, 5(1971) 480 .

7) K. Furutani, K. lida: Driving method of piezoelectric actuator by using current pulse, Meas. Sci. Technol., 17, 9 (2006) 2387.

8) W. G. May, Jr.: "Piezoelectric Electromechanical Translation Apparatus," US Pat., 3902084 (1975)

9）青山尚之, 岩崎隆之, 佐々木彰, 深谷次助, 下河辺明 : 小型自走機 械群による超精密生産機械システム(第1 報) 自走機械の設計と試作, 精密工学会誌，59，3(1993) 1007.

10) S. J. Ball, C. Folsom, and A. B. McLean: A compact nanopositioning stage with high vibrational eigenfrequencies, Rev. Sci. Instrum., 76, 113702 (2005)

11）樋口俊郎, 渡辺正浩, 工藤健一 : 圧電素子の急速変形を利用した超 精密位置決め機構，精密工学会誌，54, 11 (1988) 2107.

12) G. Mariotto, M. D'Angelo and I. V. Shvets: Dynamic behavior of a piezowalker, inertial and frictional configurations, Rev. Sci. Instrum., 70, 9 (1999) 3651.

13) J. Y. Shim, and D. G. Gweon: Piezo-driven metrological multiaxis nanopositioner, Rev. Sci. Instrum., 72, 11 (2001) 4183.

14) G. Shang, X. Qiu, C. Wang and C. Bai: Piezoelectric Push-pull Micropositioner for Ballistic Electron Emission Microscope, Rev. Sci. Instrum., 68, 10 (1997) 3803.

15) K. Furutani, M. Furuichi, N. Mohri: Coarse motion of 'seal mechanism' with three degrees of freedom by using difference of frictional force, Meas. Sci. Technol., 12, 12 (2001) 2147.

16) K. Furutani, N. Ohta, and K. Kawagoe: Coarse and Fine Positioning Performance of L-shaped Seal Mechanism with 3 Degrees of Freedom, Meas. Sci. Technol., 15, 1 (2004) 103.

17）古谷克司, 河越克己 : 3 自由度アザラシ型位置決め機構の移動特性の 改善, 電学論, 126-E, 4 (2006) 131.

18）社本英二, 申 興哲, 森脇俊道 : Walking Driveによる精密送り機構 の開発(第 1 報)Walking Drive の駆動原理と基本特性，精密工学会誌， 59, 2 (1993) 317

19) 古谷克司, 古田 淳:電流パルスによる压電アクチュエータの駆動(第 4 報駆動のシミュレーション, 2007 年度精密春季予稿 (2007) 1009

20）河越克己, 古谷克司, 鈴木教夫 : アザラシ型精密位置決め機構の性 能評価，第 44 回自動制御連合講演会前刷 (2001) 88 .

21) R. L. Norton: Machine Design - An Integrated Approach, Prentice-Hall Int., Upper Saddle River, NJ, USA (2000) 254 